\title{
Detection of E2A-PBX1 fusion transcripts in human non-small-cell lung cancer
}

\author{
Min-Li Mo ${ }^{1 \dagger}$, Zhao Chen ${ }^{1,2+}$, Hai-Meng Zhou ${ }^{1,3^{*}}$, Hui Li ${ }^{2}$, Tomomi Hirata ${ }^{2,4}$, David M Jablons ${ }^{2}$ and Biao He ${ }^{2^{*}}$
}

\begin{abstract}
Background: E2A-PBX1 fusion gene caused by $\mathrm{t}(1 ; 19)(q 23 ; p 13)$, has been well characterized in acute lymphoid leukemia (ALL). There is no report on E2A-PBX1 fusion transcripts in non-small-cell lung cancer (NSCLC).

Methods: We used polymerase chain reaction (PCR) to detect E2A-PBX1 fusion transcripts in human NSCLC tissue specimens and cell lines. We analyzed correlation of E2A-PBX1 fusion transcripts with clinical outcomes in 76 patients with adenocarcinoma in situ (AIS) and other subgroups. We compared mutation status of k-ras, p53 and EGFR in 22 patients with E2A-PBX1 fusion transcripts.

Results: We detected E2A-PBX1 transcripts in 23 of 184 (12.5\%) NSCLC tissue specimens and 3 of 13 (23.1\%) NSCLC cell lines. Presence of E2A-PBX1 fusion transcripts correlated with smoking status in female patients $(P=0.048)$, AIS histology $(P=0.006)$ and tumor size $(P=0.026)$. The overall survival was associated with gender among AlS patients $(P=0.0378)$ and AIS patients without E2A-PBX1 fusion transcripts $(P=0.0345)$, but not among AIS patients with E2A-PBX1 fusion transcripts ( $P=0.6401)$. The overall survival was also associated with status of E2A-PBX1 fusion transcripts among AIS stage IA patients $(P=0.0363)$ and AIS stage IA female patients $(P=0.0174)$. In addition, among the 22 patients with E2A-PBX1 fusion transcripts, 12 (54.5\%) patients including all four non-smokers, showed no common mutations in k-ras, p53 and EGFR.
\end{abstract}

Conclusions: E2A-PBX1 fusion gene caused by $\mathrm{t}(1 ; 19)(\mathrm{q} 23 ; \mathrm{p} 13)$ may be a common genetic change in AIS and a survival determinant for female AIS patients at early stage.

Keywords: NSCLC, Fusion gene, E2A-PBX1

\section{Background}

Lung cancer has been the leading cause of cancerrelated deaths in developed countries [1]. Non-small-cell lung cancer (NSCLC) accounts for around $80 \%$ of all lung cancer cases. Somatic events, such as point mutation, genomic rearrangements (e.g. translocation) and changes in copy number, usually cooperatively cause alterations in oncogenes, tumor-suppressor genes, and microRNA genes, and lead to the multi-step carcinogenesis [2,3]. During tumor initiation and/or progression, encoded oncogenic proteins activated by translocations or mutations can alter cell proliferation and/or apoptosis

\footnotetext{
*Correspondence: zhm-dbs@mail.tsinghua.edu.cn; biao.he@ucsfmedctr.org ${ }^{\dagger}$ Equal contributors

'School of Life Sciences, Tsinghua University, Beijing 10084, China

${ }^{2}$ Thoracic Oncology Program, Department of Surgery, Helen Diller Family Comprehensive Cancer Center, University of California, San Francisco, CA 94115, USA

Full list of author information is available at the end of the article
}

[3], resulting in transformation events. Fusion transcripts can be caused by chromosomal translocations and may occur more frequently in solid tumors than previously understood [2-4].

E2A-PBX1 fusion protein contains the transactivation domain of E2A and the DNA-binding domain of PBX1 and is generated by $\mathrm{t}(1 ; 19)(\mathrm{q} 23 ; \mathrm{p} 13)$ translocation [5]. $t(1 ; 19)$ occurs in $5 \%$ of pre-B-cell acute lymphoid leukemias (ALL) in children and adults [6] and E2A-PBX1 has been widely characterized in ALL [5-15]. E2A-PBX1 can cause transformation in several cell types in vitro and induce lymphoblastic lymphomas in transgenic mice [7-9]. Target genes of E2A-PBX1 includes fibroblast growth factor (FGF)-15 [13], WNT-16 [14], and some novel genes [10], etc. Bmi-1 regulation of INK4A-ARF was required for transformation of hematopoietic progenitors by E2A-PBX1 [15]. However, there has been no report on detection of E2A-PBX1 fusion transcripts in

\section{Biomed Central}


solid tumors. In this study, we investigated into the detection of E2A-PBX1 fusion transcripts in NSCLC and compared this genetic change with three other common mutations in NSCLC (i.e. k-ras, p53 and EGFR) [16-18]. These data suggest that E2A-PBX1 fusion transcripts caused by $\mathrm{t}(1 ; 19)(\mathrm{q} 23 ; \mathrm{p} 13)$ may be a common somatic genetic change of importance in solid tumors and E2APBX1 may be a novel target for prognosis and therapy in adenocarcinoma in situ (AIS) [19].

\section{Methods}

\section{Patients and tissue specimens}

A total of 184 patients were chosen in this study. All eligible patients without preoperative chemotherapy or radiation treatment underwent surgical resection of a primary NSCLC and had adequate mediastinal lymph node staging at UCSF between July 1997 and January 2007. Their clinical information of patients was summarized in Table 1. Information on clinical variables and patient follow-up were obtained from a prospectively maintained database including all subjects with banked tissue in the study. Patients consented to tissue specimen collection prospectively, and the study was approved by UCSF Human Research Protection Program Committee on Human Research. Tissue specimens were snap-frozen in liquid nitrogen at the time of the operation and stored in $-150^{\circ} \mathrm{C}$ freezer.

\section{Cell lines}

NSCLC cell lines A549, A427, H441, H838, H1975, H1650, H322, H358, H1666, H1703, H2170, H460 and H1299, acute lymphoblastic leukemia (ALL) cell line CCRF-CEM were obtained from ATCC and cultured as recommended. ALL cell line $\mathrm{RCH}-\mathrm{ACV}$ was a kind gift from Dr. Mignon Loh (Department of Paediatrics, UCSF).

\section{RNA extraction and polymerase chain reaction (PCR)}

Total RNA from cell lines and tissues were extracted using TRIzol reagent (Invitrogen) according to manufacture's handbook. Adult normal lung total RNA was purchased at Biochain (CA). 1 $1 \mu \mathrm{g}$ RNA was used for cDNA synthesis (BioRad). $1 \mu \mathrm{L}$ cDNA, $0.2 \mathrm{mM}$ for each dNTP, $0.4 \mu \mathrm{M}$ forward (5'-caccagcctcatgcacaa-3', according to NM_003200 1398-1416) and reverse (5' -ttt ctccagctccgtatggt-3', according to NM_002585 605-624) primers, magnesium with final concentration of $2 \mathrm{mM}$, the PCR buffer, Q-solution and $2 \mathrm{U}$ Taq enzyme provided (Qiagen) were used in the first round PCR. The reaction cycles were $95^{\circ} \mathrm{C}$ for $5 \mathrm{~min}$, followed by 30 cycles of $95^{\circ} \mathrm{C} 30 \mathrm{~s}, 55^{\circ} \mathrm{C} 30 \mathrm{~s}, 72^{\circ} \mathrm{C} 30 \mathrm{~s}$, with final extension of $7 \mathrm{~min} .1 \mu \mathrm{L}$ PCR product was used in the second round PCR. The conditions were the same except forward primer (5' -gcacaaccacgcggccc-3', according to NM_003200
1407-1423) and reverse primer (5' -ccacgccttccgctaacagc$3^{\prime}$, according to NM_002585 456-475). PCR products were run on $1.5 \%$ agarose gels and dyed with ethidium bromide. GAPDH was used as internal control. Sequencing was performed using PCR primers by Quintara (CA).

\section{DNA extraction and mutation analysis in K-ras, p53 and EGFR}

Genomic DNA was extracted from snap-frozen tissue specimens using Qiagen genomic DNA purification kit. Mutations in K-ras codon 12, p53 exons 4-8, EGFR exons 19-21 were analyzed by direct sequencing as previously reported [20-22].

\section{Statistical analysis}

The associations between the status of E2A-PBX1 fusion transcripts and clinical values were analyzed with Pearson Chi-square test and student $t$ test for category variables and continuous variables, respectively. Median survival, 95\% confidence intervals (CI) was calculated by Kaplan-Meier model and the log-rank test. A Cox regression model was used in AIS patients to assess the effects of E2A-PBX1 fusion transcripts, adjusted for gender, tumor stage, smoking status, race and Eastern Cooperative Oncology Group (ECOG) performance status. All $\mathrm{p}$ values reported were from two-sided tests. All analysis was performed by using SPSS 13.0. A p-value $\leq 0.05$ was considered as significant.

\section{Results}

Detection of E2A-PBX1 fusion transcripts in NSCLC

We performed nested PCR and detected E2A-PBX1 in 23/184 (12.5\%) NSCLC patients as well as in positive control (RCH-ACV cell line [23,24]), but not in negative control (CEM cell line $[23,24])$ or adult normal lung (Figure 1A). For the 23 patients with E2A-PBX1 fusion transcripts in their tumor tissues, we did not detect the E2A-PBX1 fusion transcripts in their paired adjacent normal tissues (figures not shown). We searched the sequencing results for all the PCR products in NCBI nucleotide/translated nucleotide/protein databases by BLAST (Basic Local Alignment Search Tool). The alignments showed that all the products we obtained were human E2A-PBX1 fusion gene with 100\% identities. We also detected and confirmed E2A-PBX1 fusion transcripts in 3/13 (23.1\%) NSCLC cell lines (Figure 1B). Furthermore, we found that all the junction sites in these specimens were the same as that reported by Nourse J, et al. [5] (sequencing examples of the sequence around the junction site in one positive NSCLC tissue sample and cell line were was shown in Figure 1C). 
Table 1 Characteristics of NSCLC patients in the study cohort

\begin{tabular}{|c|c|c|c|c|c|c|c|}
\hline & & Total (\%) & $\begin{array}{c}\text { E2A-PBX1 } \\
\text { positive (\%) }\end{array}$ & $\begin{array}{c}\text { E2A-PBX1 } \\
\text { negative (\%) }\end{array}$ & $P$ value & $\begin{array}{c}\text { Median overall } \\
\text { survival }(95 \% \mathrm{Cl})\end{array}$ & $P$ value \\
\hline & Total & $184(100)$ & $23(12.5)$ & $161(87.5)$ & & $105.60(55.41 \sim 155.79)$ & \\
\hline \multicolumn{8}{|c|}{ Age } \\
\hline & Mean (years) & $66.9 \pm 12.0$ & $66.0 \pm 11.7$ & $67.0 \pm 12.1$ & $0.698^{*}$ & & \\
\hline & Range (years) & $25-91$ & $39-84$ & 25-91 & & & \\
\hline & $<71$ & $109(100)$ & $13(11.9)$ & $96(88.1)$ & 0.777 & $69.00(43.73 \sim 94.27)$ & 0.7069 \\
\hline & $\geq 71$ & $75(100)$ & $10(13.3)$ & $65(86.7)$ & & $105.60(18.53 \sim 192.67)$ & \\
\hline \multicolumn{2}{|c|}{ Gender } & & & & 0.215 & & \\
\hline & Male & $78(100)$ & $7(9.0)$ & $71(91.0)$ & & $64.70(\mathrm{NA})$ & 0.0889 \\
\hline & Female & $106(100)$ & $16(15.1)$ & $90(84.9)$ & & $105.60(57.58 \sim 153.62)$ & \\
\hline \multirow[t]{6}{*}{ Rac } & & & & & 0.606 & & 0.1430 \\
\hline & Caucasian & $136(100)$ & $17(12.5)$ & $119(87.5)$ & & $81.70(52.59 \sim 110.81)$ & \\
\hline & Asian & $27(100)$ & $3(11.1)$ & $24(88.9)$ & & $64.70(45.79 \sim 83.61)$ & \\
\hline & Hispanic & $7(100)$ & $2(28.6)$ & $5(71.4)$ & & NR & \\
\hline & African-American & $7(100)$ & 0 & $7(100)$ & & NR & \\
\hline & Others & $7(100)$ & $1(14.3)$ & $6(85.7)$ & & & \\
\hline \multicolumn{2}{|c|}{ Smoking } & & & & 0.174 & & 0.0868 \\
\hline & Smoker & $127(100)$ & $19(15.0)$ & $108(85.0)$ & & $69.00(42.36 \sim 95.64)$ & \\
\hline & Non-smoker & $53(100)$ & $4(7.5)$ & $49(92.5)$ & & $105.60(35.86 \sim 175.34)$ & \\
\hline & Unknown & $4(100)$ & 0 & $4(100)$ & & & \\
\hline \multicolumn{8}{|c|}{ Pack/Year (smoker) } \\
\hline & Mean & $41.6 \pm 23.5$ & $46.3 \pm 26.7$ & $30.9 \pm 35.9$ & $0.623^{*}$ & & \\
\hline & Range & $1-160$ & $5-90$ & $1-160$ & & & \\
\hline \multicolumn{3}{|c|}{ Gender $\times$ Smoking } & & & 0.097 & & 0.0258 \\
\hline & Male, Smoker & $59(100)$ & $5(8.5)$ & $54(91.5)$ & $0.733^{1}$ & $56.20(27.25 \sim 85.15)$ & $0.0749^{1}$ \\
\hline & Male, Non-smoker & $18(100)$ & $2(11.1)$ & $16(88.9)$ & & NR & \\
\hline & Female, Smoker & $68(100)$ & $14(20.6)$ & $54(79.4)$ & $0.048^{2}$ & $81.70(41.68 \sim 121.72)$ & $0.6714^{2}$ \\
\hline & Female, Non-smoker & $35(100)$ & $2(5.7)$ & $33(94.3)$ & & $105.60(35.04 \sim 176.16)$ & \\
\hline & Unkown & $4(100)$ & 0 & $4(100)$ & & & \\
\hline \multicolumn{2}{|c|}{ Histology } & & & & 0.276 & & 0.6013 \\
\hline & AIS & $76(100)$ & $17(22.4)$ & $59(77.6)$ & $0.006^{3}$ & $105.60(57.93 \sim 153.27)$ & $0.1208^{3}$ \\
\hline & Invasive adenocarcinoma & $76(100)$ & $5(6.6)$ & $71(93.4)$ & & $53.10(\mathrm{NA})$ & \\
\hline & Squamous cell carcinoma & $18(100)$ & 0 & $18(100)$ & & NR & \\
\hline & Carcinoid & $6(100)$ & 0 & $6(100)$ & & NR & \\
\hline & Large & $4(100)$ & $1(25.0)$ & $3(75.0)$ & & NR & \\
\hline & Others & $4(100)$ & 0 & $4(100)$ & & & \\
\hline \multicolumn{2}{|c|}{ Tumor Size } & & & & $0.026^{*}$ & & \\
\hline & Mean & $3.3 \pm 1.9$ & $4.1 \pm 2.8$ & $3.2 \pm 1.7$ & & & \\
\hline & Range & $0.5-13.0$ & $0.9-12.0$ & $0.5-13.0$ & & & \\
\hline \multicolumn{8}{|c|}{ Pathological TNM Classification } \\
\hline \multirow[t]{5}{*}{ pt } & pt1 & $74(100)$ & $9(12.2)$ & $65(87.8)$ & 0.408 & $105.60(\mathrm{NA})$ & 0.0915 \\
\hline & pt2 & $81(100)$ & $9(11.1)$ & $72(88.9)$ & & $69.00(44.22 \sim 93.78)$ & \\
\hline & pt3 & $8(100)$ & 0 & $8(100)$ & & $40.20(26.06 \sim 54.34)$ & \\
\hline & pt4 & $18(100)$ & $4(22.2)$ & $14(77.8)$ & & $30.50(\mathrm{NA})$ & \\
\hline & Unknown & $3(100)$ & $1(33.3)$ & $2(66.6)$ & & & \\
\hline
\end{tabular}


Table 1 Characteristics of NSCLC patients in the study cohort (Continued)

\begin{tabular}{|c|c|c|c|c|c|c|c|}
\hline \multirow[t]{5}{*}{$\overline{\mathrm{pn}}$} & pno & $144(100)$ & $18(12.5)$ & $126(87.5)$ & \multirow[t]{5}{*}{0.924} & $105.60(65.68 \sim 145.52)$ & \multirow[t]{5}{*}{0.0038} \\
\hline & pn1 & $19(100)$ & $3(15.8)$ & $16(84.2)$ & & $47.80(32.55 \sim 63.05)$ & \\
\hline & $\mathrm{pn} 2$ & $17(100)$ & $2(11.8)$ & $15(88.2)$ & & 45.50 (NA) & \\
\hline & pn3 & $2(100)$ & 0 & $2(100)$ & & $5.20(\mathrm{NA})$ & \\
\hline & Unknown & $2(100)$ & 0 & $2(100)$ & & & \\
\hline \multirow[t]{2}{*}{ pm } & pmo & $171(100)$ & $20(11.7)$ & $151(88.3)$ & \multirow[t]{2}{*}{0.179} & $105.60(55.99 \sim 155.21)$ & \multirow[t]{2}{*}{0.2605} \\
\hline & pm1 & $12(100)$ & $3(25.0)$ & $9(75.0)$ & & $56.20(35.26 \sim 77.14)$ & \\
\hline \multicolumn{3}{|c|}{ Pathological Stage } & & & \multirow[t]{6}{*}{0.426} & & \multirow[t]{6}{*}{0.0167} \\
\hline & Stage I & $119(100)$ & $13(10.9)$ & $106(89.1)$ & & $105.60(65.47 \sim 145.73)$ & \\
\hline & Stage II & $22(100)$ & $2(9.1)$ & $20(90.9)$ & & NR & \\
\hline & Stage III & $29(100)$ & $5(17.2)$ & $24(82.8)$ & & $33.60(0.00 \sim 73.11)$ & \\
\hline & Stage IV & $12(100)$ & $3(25.0)$ & $9(75.0)$ & & $56.20(35.26 \sim 77.14)$ & \\
\hline & Unknown & $2(100)$ & 0 & $2(100)$ & & & \\
\hline \multicolumn{2}{|c|}{ Recurrence } & & & & \multirow[t]{4}{*}{0.435} & & \multirow[t]{4}{*}{$<0.001$} \\
\hline & Yes & $63(100)$ & $6(9.5)$ & $57(90.5)$ & & $39.30(30.45 \sim 48.15)$ & \\
\hline & No & $103(100)$ & $14(13.6)$ & $89(86.4)$ & & \multirow[t]{2}{*}{ NR } & \\
\hline & Unknown & $18(100)$ & $1(5.6)$ & 17 (94.4) & & & \\
\hline
\end{tabular}

* student $t$ test.

1 between male smoker and male non-smoker.

2 between female smoker and female non-smoker.

3 between AIS and invasive adenocarcinoma.

AIS: adenocarcinoma in situ; NR: not reached; NA: not available.

\section{Association of E2A-PBX1 fusion transcripts with} clinicopathological characteristics of NSCLC patients We next analyzed association of the expression of E2APBX1 fusion transcripts and patients' characteristics (Table 1). Smoking status was not significantly associated with the frequency of E2A-PBX1 fusion transcripts in all patients $(19 / 127(15.0 \%)$ in smokers and $4 / 56(7.5 \%)$ in non-smokers $(\mathrm{p}=0.174))$, or in male patients $(5 / 59(8.5 \%)$ in smokers and $2 / 18(11.1 \%)$ in non-smokers $(\mathrm{p}=0.733)$. On the other hand, the frequency of E2A-PBX1 fusion

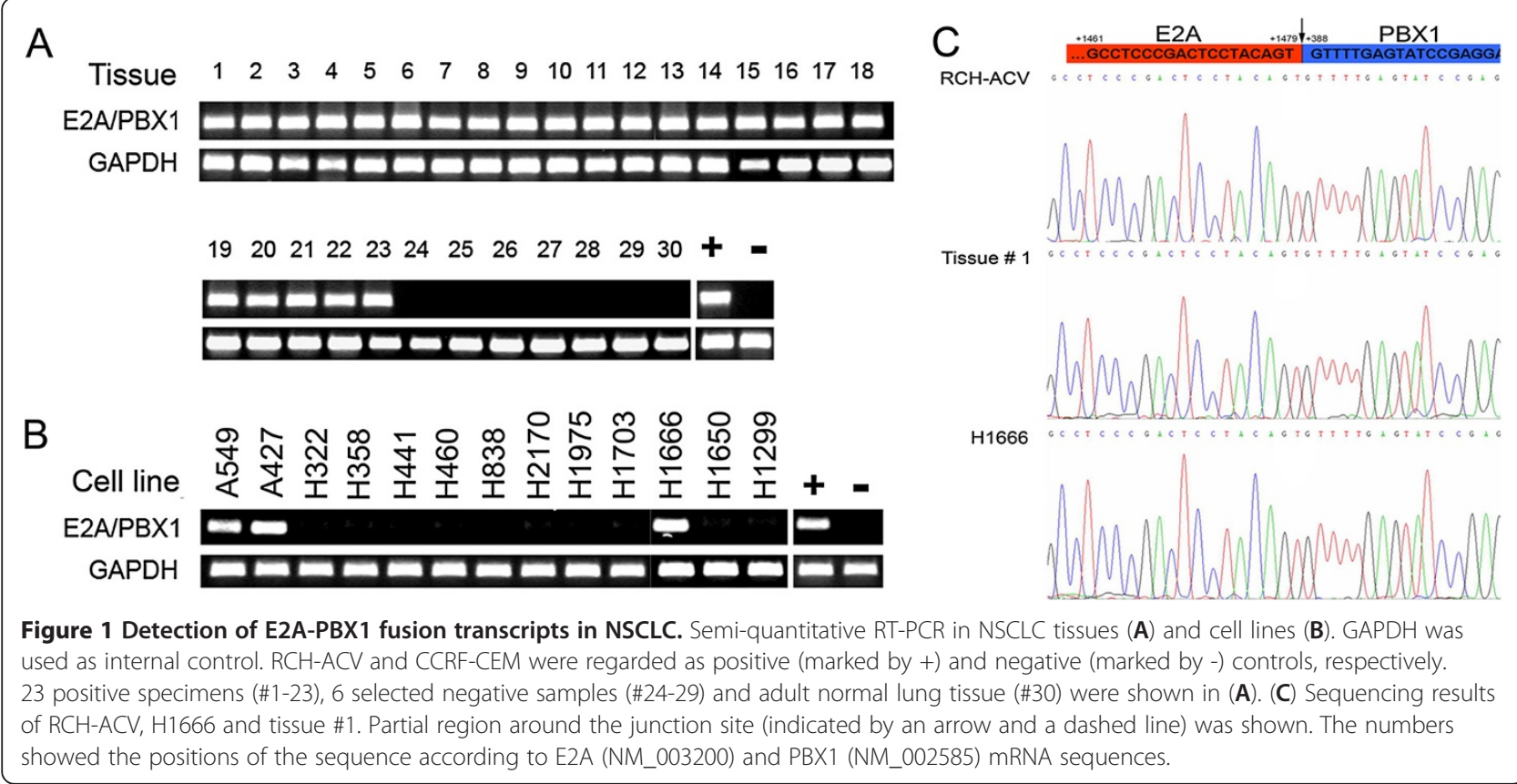


transcripts in female smokers (14/68 (20.6\%)) was significantly higher than that in female non-smokers $(2 / 35$ $(5.7 \%))(\mathrm{p}=0.048)$. The odds ratio for female smoker/nonsmoker was 4.278 , and $95 \%$ CI was from 0.914 to 20.026 , also suggesting that the expression of E2A-PBX1 fusion transcripts correlated with smoking status among female patients with NSCLC.

The frequencies of E2A-PBX1 fusion transcripts in adenocarcinomas, squamous cell carcinomas, carcinoids and large cell carcinomas were 22/152 (14.5\%), 0/18 (0\%), $0 / 6(0 \%), 1 / 4(25 \%)$, respectively $(\mathrm{p}=0.276)$ (Table 1$)$. Interestingly, the frequency of E2A-PBX1 fusion transcripts in patients with AIS (17/76 (22.4\%)) was significantly higher $(\mathrm{p}=0.006)$ than that in patients with invasive adenocarcinoma (5/76 (6.6\%)) (Table 1). The odds ratio for AIS/invasive adenocarcinoma was 4.092, and $95 \%$ CI was from 1.424 to 11.753 , suggesting significant correlation between the expression of E2A-PBX1 fusion transcripts and patients with AIS. Moreover, the mean tumor size in patients with E2A-PBX1 fusion transcripts $(4.1 \pm 2.8 \mathrm{~cm})$ was significantly larger than that in patients without E2A-PBX1 fusion transcripts $(3.2 \pm 1.7 \mathrm{~cm})$ $(\mathrm{p}=0.026)$ (Table 1$)$. There was no significant association between expression of E2A-PBX1 fusion transcripts and age, gender, race, stage, or recurrence status (Table 1).

\section{Association of E2A-PBX1 fusion transcripts with overall survival in AIS patients}

In our study cohort of patients with AIS, females had significantly better overall survival (OS) than males $(\mathrm{p}=0.0378$; hazard ratio $0.3647 ; 95 \% \mathrm{CI}, 0.1395 \sim 0.9532)$ (Table 2, Figure 2A), consistent with known data [25]. When these AIS patients were grouped by gender and expression of E2A-PBX1 fusion transcripts, no significant difference in OS was found between females and males in AIS patients with E2A-PBX1 fusion transcripts $(\mathrm{p}=0.6401)$ (Figure 2B). In patients without E2A-PBX1 fusion transcripts, however, females had significantly better OS than males ( $\mathrm{p}=0.0345$; hazard ratio 0.2687 ; $95 \% \mathrm{CI}$, $0.07945 \sim 0.9089$ ) (Figure 2C). In addition, Kaplan-Meier analysis demonstrated an association between expression of E2A-PBX1 fusion transcripts and OS by stage. A statistically significant difference in OS was not observed in stage I patients (Figure 2D). OS was significantly better in E2A-PBX1 fusion transcripts (-) group than that in E2APBX1 fusion transcripts (+) group in stage IA patients with AIS $(\mathrm{p}=0.0363$; hazard ration $0.04104 ; 95 \% \mathrm{CI}, 0.002065$ $\sim 0.8157$ ) (Figure 2E) and female stage IA patients with AIS ( $\mathrm{p}=0.0174$; hazard ration 0.02174; 95\% CI, 0.0009266 $\sim 0.5100$ ) (Figure $2 \mathrm{~F}$ ). A multivariate analysis also showed that the status of E2A-PBX1 fusion transcripts $(\mathrm{P}=0.050$; hazard ratio 3.447; 95\% CI, $1.002 \sim 11.857)$, gender $(\mathrm{p}=$ 0.005 ; hazard ratio 0.212 ; 95\% CI, $0.071 \sim 0.628$ ) and stage IA $(\mathrm{p}=0.004$; hazard ratio $0.011 ; 95 \% \mathrm{CI}, 0.001 \sim 0.237$ ) were significantly associated with overall survival.

\section{E2A-PBX1 fusion transcripts as a potential genetic biomarker in AIS}

Mutations in K-ras, p53 and EGFR are commonly found in NSCLC [16-18]. We next screened for mutations in

Table 2 Overall survival analysis in AIS patients and subgroups

\begin{tabular}{|c|c|c|c|c|c|c|}
\hline Group & Gender & $\begin{array}{c}\text { E2A-PBX1 } \\
\text { status }\end{array}$ & $\begin{array}{l}\text { Patient } \\
\text { number }\end{array}$ & $\begin{array}{l}\text { Median survival } \\
\text { (months) }\end{array}$ & $95 \% \mathrm{Cl}$ & $P$ value \\
\hline \multirow[t]{2}{*}{ AIS patients } & Female & & 53 & 105.60 & $63.95 \sim 147.25$ & 0.0378 \\
\hline & Male & & 23 & 56.20 & $22.34 \sim 90.06$ & \\
\hline \multirow[t]{2}{*}{ AIS patients with E2A-PBX1 } & Female & & 12 & 56.20 & $37.46 \sim 74.94$ & 0.6401 \\
\hline & Male & & 5 & 56.20 & $0.00 \sim 122.80$ & \\
\hline \multirow[t]{2}{*}{ AIS patients without E2A-PBX1 } & Female & & 41 & 105.60 & $63.45 \sim 147.75$ & 0.0345 \\
\hline & Male & & 18 & $N R$ & NA & \\
\hline \multirow[t]{2}{*}{ AIS patients } & & + & 17 & 56.20 & $44.37 \sim 68.03$ & 0.1235 \\
\hline & & - & 59 & 105.60 & $63.95 \sim 147.25$ & \\
\hline \multirow[t]{2}{*}{ AIS stage I patients } & & + & 10 & 56.20 & $38.38 \sim 74.02$ & 0.1753 \\
\hline & & - & 41 & 105.60 & $63.65 \sim 147.55$ & \\
\hline \multirow[t]{2}{*}{ AIS female patients } & & + & 12 & 56.20 & $37.46 \sim 74.94$ & 0.0747 \\
\hline & & - & 41 & 105.60 & $63.45 \sim 147.75$ & \\
\hline \multirow[t]{2}{*}{ AIS stage IA patients } & & + & 6 & NR & NA & 0.0363 \\
\hline & & - & 18 & NR & NA & \\
\hline \multirow[t]{2}{*}{ AIS stage IA female patients } & & + & 4 & 46.70 & $8.77 \sim 84.63$ & 0.0174 \\
\hline & & - & 13 & 105.60 & NA & \\
\hline
\end{tabular}




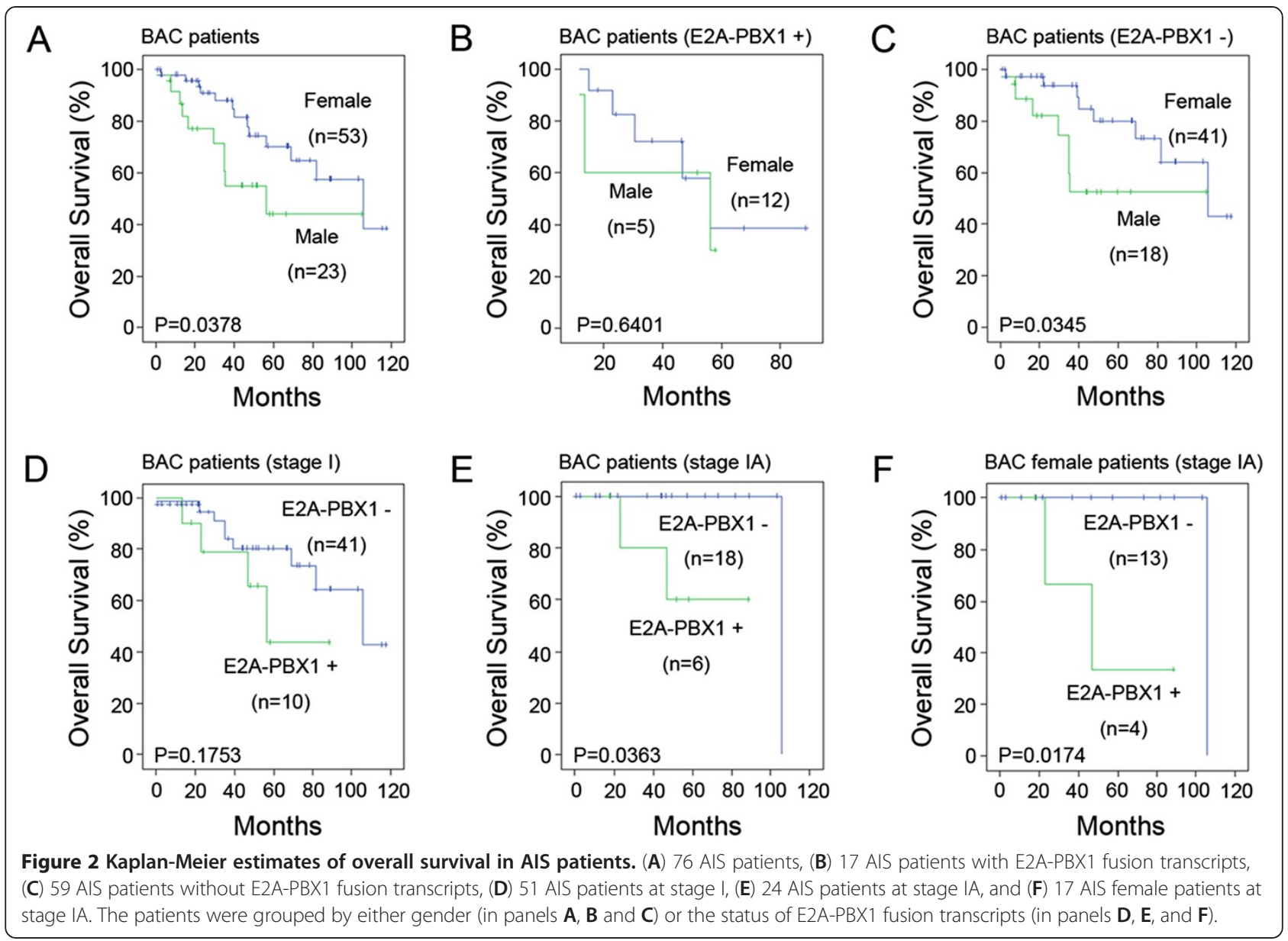

codon 12 of K-ras, exons 4-8 of p53, and exons 19-21 of EGFR in the specimens form patients with expression of E2A-PBX1 fusion transcripts. We also compared the status of E2A-PBX1 fusion transcripts and mutation status of K-ras, p53 and EGFR in the NSCLC cell lines used in our study (mutation information was obtained from The COSMIC (Catalogue of Somatic Mutations in Cancer) database and website [25]) (Table 3 and Table 4). 8 of these $22(36.4 \%)$ patients with E2A-PBX1 fusion transcripts had K-ras mutations; 3 of the $22(13.6 \%)$ patients had p53 mutations; only 1 of the $22(4.5 \%)$ patient had EGFR mutation. K-ras and EGFR mutations in these patients were mutually exclusive to each other, same as previously reporeted [26]. Notably, 12 of the 22 (54.5\%) patients had none of these three common mutations in lung cancer (Table 3 and Table 4). This subgroup of patients included all four non-smokers (patient \# 4, 8, 13 and 22) and 8 stage I patients with AIS (Table 3). Among all thirteen NSCLC cell lines that we examined, only H1666 that was derived from a female patient with BAC (non-smoker) had no mutations in K-ras, p53 and EGFR (Note: the histology information of H1666 from ATCC still uses BAC). Taken together, our results suggest that the E2A-PBX1 fusion gene may be a genetic biomarker in NSCLC, especially in its subtype AIS.

\section{Discussion}

Somatic genetic changes have been believed to play important roles in human tumorigenesis, but the cancer type in which somatic rearrangement occurs is limited to leukemias, lymphomas and soft tissue tumors [2]. Overexpression of Notch3 was found to be associated with chromosome 19 translocation in lung cancer [27]. EML4-ALK fusion gene [28] and ETS fusion genes $[29,30]$ exist in NSCLC and prostate cancer, respectively. It is still unclear whether chromosome aberrations are important in the initiation of epithelial tumorigenesis.

AIS (formerly named BAC) is a subset of adenocarcinoma characterized by non-invasive growth along alveolar septae $[19,25]$. It is more prevalent in women, nonsmokers, and Asians [25]. Despite the lack of stromal, vascular, or pleural invasion, AIS is malignant and surgical resection is currently the mainstay of curative treatment. We previously discussed about a multi-step model of lung cancer development, especially AIS as carcinoma in situ [31]. Genetic changes can sequentially accumulate 
Table 3 Mutational analysis of K-ras, p53 and EGFR in NSCLC patients with E2A-PBX1 fusion transcripts and NSCLC cell lines

\begin{tabular}{|c|c|c|c|c|c|c|c|c|c|c|}
\hline$\#$ & E2A-PBX1 & $\begin{array}{c}\text { k-Kras } \\
\text { codon } 12\end{array}$ & p53 & EGFR & Age & Gender & Race & $\begin{array}{c}\text { Smoking } \\
\text { status }\end{array}$ & Stage & Histology \\
\hline 2 & + & & & & 67 & $M$ & Middle Eastern & $S$ & $\| I I B$ & Adc \\
\hline 12 & + & & & & 72 & $\mathrm{~F}$ & Hispanic & S & $\mathrm{IB}$ & Adc \\
\hline 14 & + & & & & 66 & $\mathrm{~F}$ & Caucasian & S & $\| \mathrm{B}$ & Adc \\
\hline 18 & + & G12V & & & 78 & $\mathrm{~F}$ & Caucasian & S & $\mathrm{IB}$ & Adc \\
\hline 20 & + & $\mathrm{G} 12 \mathrm{C}$ & & & 63 & $\mathrm{~F}$ & Caucasian & S & IV & Adc \\
\hline 1 & + & & & & 71 & $\mathrm{~F}$ & Caucasian & S & IA & AIS \\
\hline 3 & + & & & & 41 & M & Caucasian & S & IV & AIS \\
\hline 8 & + & & & & 59 & M & Caucasian & NS & $\mathrm{IB}$ & AIS \\
\hline 9 & + & & & & 73 & $\mathrm{~F}$ & Caucasian & S & $\| I \mathrm{~B}$ & AIS \\
\hline 11 & + & & & & 84 & M & Caucasian & S & IA & AIS \\
\hline 13 & + & & & & 61 & $\mathrm{~F}$ & South Asian & NS & $\mathrm{IB}$ & AIS \\
\hline 21 & + & & & & 82 & $\mathrm{~F}$ & Caucasian & S & IA & AIS \\
\hline 22 & + & & & & 48 & $\mathrm{~F}$ & East Asian & NS & $\mathrm{IB}$ & AIS \\
\hline 16 & + & & G245S & & 63 & $\mathrm{~F}$ & Caucasian & S & IA & AIS \\
\hline 7 & + & & V272M & L858R & 73 & $\mathrm{~F}$ & Caucasian & S & $\| I B$ & AIS \\
\hline 6 & + & G12C & & & 68 & M & Southeast Asian & S & $\| \mathrm{A}$ & AIS \\
\hline 10 & + & G12C & & & 71 & M & Hispanic & S & IA & AIS \\
\hline 17 & + & G12C & & & 67 & $\mathrm{~F}$ & Caucasian & S & IB & AIS \\
\hline 19 & + & $\mathrm{G} 12 \mathrm{C}$ & & & 79 & $\mathrm{~F}$ & Caucasian & S & $\| \mathrm{A}$ & AIS \\
\hline 5 & + & G12A & & & 54 & $\mathrm{~F}$ & Caucasian & S & $\| I I B$ & AIS \\
\hline 15 & + & G12V & exon 7(FS) & & 67 & $\mathrm{~F}$ & Caucasian & S & IV & AIS \\
\hline 4 & + & & & & 39 & M & Caucasian & NS & $\mathrm{IB}$ & LCC \\
\hline 23 & + & ND & 72 & $\mathrm{~F}$ & Caucasian & S & $\mid A$ & AIS & & \\
\hline \multicolumn{11}{|l|}{ Cell line } \\
\hline A549 & + & G12S & & & 58 & M & Caucasian & & & Adc \\
\hline A427 & + & G12D & & & 52 & M & Caucasian & & & Adc \\
\hline $\mathrm{H} 441$ & - & G12V & R158L & & & M & & & & Adc \\
\hline H838 & - & & & & 59 & M & Caucasian & S & $\| I B$ & Adc \\
\hline $\mathrm{H} 1975$ & - & & $\mathrm{R} 273 \mathrm{H}$ & L858R, T790M & & $\mathrm{F}$ & & NS & & Adc \\
\hline $\mathrm{H} 1650$ & - & & & Exon 19 deletion & 27 & M & Caucasian & S & $\| I B$ & Adc \\
\hline H322 & - & & R248L & & 52 & M & Caucasian & & & BAC \\
\hline H358 & - & $\mathrm{G} 12 \mathrm{C}$ & Null & & & M & Caucasian & & & BAC \\
\hline H1666 & + & & & & 50 & $\mathrm{~F}$ & Caucasian & NS & III? & BAC \\
\hline $\mathrm{H} 2170$ & - & & R158G & & & M & & NS & & Sqc \\
\hline $\mathrm{H} 1703$ & - & & E285K & & 54 & M & Caucasian & S & I & Sqc \\
\hline $\mathrm{H} 460$ & - & Q61H & & & & M & & & & LCC \\
\hline H1299 & - & & Null & & 43 & M & Caucasian & & & LCC \\
\hline
\end{tabular}

FS: frame shift; M: male; F: female; S: smoker; NS: non-smoker; Adc: adenocarcinoma; AIS: adenocarcinoma in situ; BAC: brochioloalveolar carcinoma (histology information from ATCC still uses BAC); LCC: large cell carcinoma; Sqc: squamous carcinoma; ND: not determined. 
Table 4 Summary of mutational analysis in NSCLC patients with E2A-PBX1 fusion transcripts

\begin{tabular}{|c|c|c|c|c|c|c|c|c|c|c|}
\hline & & Total (\%) & K-P-E- & $\mathrm{K}+\mathrm{P}-\mathrm{E}-$ & $K-P+E-$ & $\mathrm{K}+\mathrm{P}+\mathrm{E}-$ & K-P + E+ & K-P-E+ & $\mathrm{K}+\mathrm{P}-\mathrm{E}+$ & $\mathrm{K}+\mathrm{P}+\mathrm{E}+$ \\
\hline Total & & $22(100)$ & $12(54.5)$ & 7 (31.8) & $1(4.5)$ & $1(4.5)$ & $1(4.5)$ & & & \\
\hline \multirow[t]{2}{*}{ Gender } & $\mathrm{F}$ & $15(100)$ & $7(46.7)$ & $5(33.3)$ & $1(6.7)$ & $1(6.7)$ & $1(6.7)$ & & & \\
\hline & M & $7(100)$ & $5(71.4)$ & $2(28.6)$ & & & & & & \\
\hline \multirow[t]{4}{*}{ Race } & Caucasian & $16(100)$ & $8(50.0)$ & $5(31.3)$ & $1(6.3)$ & $1(6.3)$ & $1(6.3)$ & & & \\
\hline & Asian & $3(100)$ & $2(66.7)$ & 1 (33.3) & & & & & & \\
\hline & Middle eastern & $1(100)$ & $1(100)$ & & & & & & & \\
\hline & Hispanic & $2(100)$ & $1(50.0)$ & $1(50.0)$ & & & & & & \\
\hline \multirow[t]{2}{*}{ Smoking status } & NS & $4(100)$ & $4(100)$ & & & & & & & \\
\hline & $S$ & $18(100)$ & $8(44.4)$ & 7 (38.9) & $1(5.6)$ & $1(5.6)$ & $1(5.6)$ & & & \\
\hline \multirow[t]{4}{*}{ Stage } & I & $12(100)$ & $8(66.7)$ & $3(25.0)$ & $1(8.3)$ & & & & & \\
\hline & $\|$ & $2(100)$ & $1(50.0)$ & $1(50.0)$ & & & & & & \\
\hline & III & $5(100)$ & $2(40.0)$ & $2(40.0)$ & & & $1(20.0)$ & & & \\
\hline & IV & $3(100)$ & 1 (33.3) & 1 (33.3) & & $1(33.3)$ & & & & \\
\hline \multirow[t]{3}{*}{ Histology } & AIS & $16(100)$ & $8(50.0)$ & $5(31.3)$ & $1(6.3)$ & $1(6.3)$ & $1(6.3)$ & & & \\
\hline & Invasive Adc & $5(100)$ & $3(60.0)$ & $2(40.0)$ & & & & & & \\
\hline & LCC & $1(100)$ & 1 (100) & & & & & & & \\
\hline
\end{tabular}

K: k-ras codon 12; P: p53 exons 4-8; E: EGFR exons 19-21.

and cause bronchioalveolar stem cells to transform, leading to development of invasive phenotype in human cancers. However, it is unclear what is the cause for transformation of atypical bronchioloalveolar cells into invasive adenocarcinoma or maintenance for the growth characterization in AIS. Several important players such as K-ras, p53, and survivin, etc. have been considered as tumor markers in AIS progression into invasive cancer [16-18,25], few are specific to AIS and "driver mutations" for AIS progression are still unidentified. Here in this study, we reported in NSCLC the expression of E2APBX1 fusion transcripts that have been well documented in leukemias [5-15]. This is the first report of detection of the E2A-PBX1 fusion transcripts in solid tumors. More interestingly, we observed that the E2A-PBX1 fusion transcripts were more frequently found in AIS than other subtypes of NSCLC, and the presence of E2A-PBX1 fusion transcripts were significantly associated with decreased overall survival in female and stage IA patients with AIS. These results suggest that the E2A-PBX1 fusion transcripts may play a critical role in AIS progression, especially for females and non-smokers. Supportive evidence also comes from our analysis of mutations in K-ras, p53 and EGFR that are common in NSCLC and considered as "driver mutations" [16-18]. Comparison of the mutational status of these genes in patients expressing the E2A-PBX1 fusion transcripts showed that approximately $55 \%$ patients examined in our study cohort were wild type in K-ras, p53 and EGFR. Majority of this subgroup were patients with AIS including all four non-smokers. Because E2A-PBX1 onco-protein has been proved to exhibit transformation potentials by transcribing target genes [5-15], we argue that E2A-PBX1 may serve as one "driver mutation" in AIS and play critical roles during initiation and progression of at least a subset of AIS. E2A-PBX1 may represent a new therapeutic target for NSCLC, especially AIS. Further investigation is needed to evaluate the function of E2APBX1 fusion protein, as well as its therapeutic and prognostic values and its correlation with treatment resistance in AIS.

In this study, we only examined in NSCLC specimens the conserved E2A-PBX1 fusion transcripts that are well documented in leukemias [5-15]. It is possible that other forms of E2A-PBX1 fusion transcripts also exist in NSCLC. TCGA (The Cancer Genome Atlas) data may be useful to analyze the frequency of E2A-PBX1 fusion transcriptions in NSCLC. Another limitation of this study is relatively small number of AIS specimens analyzed. Analysis of an independent large cohort of AIS is needed to validate our observation.

\section{Conclusions}

Our data demonstrated the presence of E2A-PBX1 fusion transcripts caused by $\mathrm{t}(1 ; 19)(\mathrm{q} 23 ; \mathrm{p} 13)$ in lung adenocarcinomas, especially AIS. It may be a common genetic change in AIS and a survival determinant for female AIS patients at early stage. These data may be of significant clinical importance, because finding reliable genetic biomarkers for early-stage lung adenocarcinomas including AIS is becoming increasingly apparent for early identification and management of this deadly disease. 


\section{Consent}

Written informed consent was obtained from the patient for publication of this report and any accompanying images.

\section{Competing interest}

The authors declare that they have no competing interests.

\section{Authors' contributions}

MLM carried out the RNA extraction, primer design and PCR. TH carried out the DNA extraction and sequencing analysis. $\mathrm{ZC}$ and $\mathrm{HL}$ performed the statistical analysis. DJ participated in the design of the study. $\mathrm{HMZ}$ and $\mathrm{BH}$ conceived of the study, and participated in its design and coordination and helped to draft the manuscript. All authors read and approved the final manuscript.

\section{Acknowledgement}

This work was supported by a Research Grant from The Joan's Legacy Lung Cancer Foundation and NIH Grant R01 CA125030 (to B. He); by the Larry Hall and Zygielbaum Memorial Trust, and the Kazan, McClain, Edises, Abrams, Fernandez, Lyons\& Farrise Foundations (to D.M. Jablons); by the National Key Basic Research and Development (973) Program of China No. 2011CB910800 and No. 2012 CB917304 (to H.M. Zhou); and by the China Natural Science Foundation No. 31170732 and No. 31270854 (to H.M. Zhou).

\section{Author details}

${ }^{1}$ School of Life Sciences, Tsinghua University, Beijing 10084, China. ${ }^{2}$ Thoracic Oncology Program, Department of Surgery, Helen Diller Family Comprehensive Cancer Center, University of California, San Francisco, CA 94115, USA. ${ }^{3}$ Zhejiang Provincial Key Laboratory of Applied Enzymology, Yangtze Delta Region Institute of Tsinghua University, Jiaxing 314006, Zhejiang, China. ${ }^{4}$ Department of Surgery, Division of Thoracic Surgery, Nippon Medical School, Tokyo 113-8602, Japan.

Received: 20 February 2013 Accepted: 15 April 2013

Published: 20 May 2013

\section{References}

1. Jemal A, Siegel R, Ward E, Hao Y, Xu J, Murray T, Thun MJ: Cancer statistics, 2008. CA Cancer J Clin 2008, 58:71-96.

2. Campbell PJ, Stephens PJ, Pleasance ED, O'Meara S, Li H, Santarius T, Stebbings LA, Leroy C, Edkins S, Hardy C, et al: Identification of somatically acquired rearrangements in cancer using genome-wide massively parallel paired-end sequencing. Nat Genet 2008, 40:722-729.

3. Croce CM: Oncogenes and cancer. N Engl J Med 2008, 358:502-511.

4. Mitelman F, Johansson B, Mertens F: Fusion genes and rearranged genes as a linear function of chromosome aberrations in cancer. Nat Genet 2004, 36:331-334.

5. Nourse J, Mellentin JD, Galili N, Wilkinson J, Stanbridge E, Smith SD, Cleary ML: Chromosomal translocation $t(1 ; 19)$ results in synthesis of a homeobox fusion mRNA that codes for a potential chimeric transcription factor. Cell 1990, 60:535-545.

6. Wiemels JL, Leonard BC, Wang Y, Segal MR, Hunger SP, Smith MT, Crouse V, Ma X, Buffler PA, Pine SR: Site-specific translocation and evidence of postnatal origin of the $t(1 ; 19)$ E2A-PBX1 fusion in childhood acute lymphoblastic leukemia. Proc Natl Acad Sci USA 2002, 99:15101-15106.

7. Dedera DA, Waller EK, LeBrun DP, Sen-Majumdar A, Stevens ME, Barsh GS, Cleary ML: Chimeric homeobox gene E2A-PBX1 induces proliferation, apoptosis, and malignant lymphomas in transgenic mice. Cell 1993, 74:833-843

8. Kamps MP, Wright DD: Oncoprotein E2A-Pbx1 immortalizes a myeloid progenitor in primary marrow cultures without abrogating its factordependence. Oncogene 1994, 9:3159-3166.

9. Monica K, LeBrun DP, Dedera DA, Brown R, Cleary ML: Transformation properties of the E2a-Pbx1 chimeric oncoprotein: fusion with E2a is essential, but the Pbx1 homeodomain is dispensable. Mol Cell Biol 1994, 14:8304-8314

10. Fu X, Kamps MP: E2a-Pbx1 induces aberrant expression of tissue-specific and developmentally regulated genes when expressed in NIH 3T3 fibroblasts. Mol Cell Biol 1997, 17:1503-1512
11. Hunger SP, Galili N, Carroll AJ, Crist WM, Link MP, Cleary ML: The $t(1 ; 19)$ (q23;p13) results in consistent fusion of E2A and PBX1 coding sequences in acute lymphoblastic leukemias. Blood 1991, 77:687-693.

12. Kamps MP, Look AT, Baltimore $D$ : The human $t(1 ; 19)$ translocation in pre-B ALL produces multiple nuclear E2A-Pbx1 fusion proteins with differing transforming potentials. Genes Dev 1991, 5:358-368.

13. McWhirter JR, Goulding M, Weiner JA, Chun J, Murre C: A novel fibroblast growth factor gene expressed in the developing nervous system is a downstream target of the chimeric homeodomain oncoprotein E2A-Pbx1. Development 1997, 124:3221-3232.

14. McWhirter JR, Neuteboom ST, Wancewicz EV, Monia BP, Downing JR, Murre $\mathrm{C}$ : Oncogenic homeodomain transcription factor E2A-Pbx1 activates a novel WNT gene in pre-B acute lymphoblastoid leukemia. Proc Natl Acad Sci USA 1999, 96:11464-11469.

15. Smith KS, Chanda SK, Lingbeek M, Ross DT, Botstein D, van Lohuizen M, Cleary ML: Bmi-1 regulation of INK4A-ARF is a downstream requirement for transformation of hematopoietic progenitors by E2a-Pbx1. Mol Cell 2003, 12:393-400.

16. Mounawar M, Mukeria A, Le Calvez F, Hung RJ, Renard H, Cortot A, Bollart C, Zaridze D, Brennan P, Boffetta P, et al: Patterns of EGFR, HER2, TP53, and KRAS mutations of p14arf expression in non-small cell lung cancers in relation to smoking history. Cancer Res 2007, 67:5667-5672.

17. Sonobe M, Manabe T, Wada H, Tanaka F: Mutations in the epidermal growth factor receptor gene are linked to smoking-independent, lung adenocarcinoma. Br J Cancer 2005, 93:355-363.

18. Sonobe M, Manabe T, Wada H, Tanaka F: Lung adenocarcinoma harboring mutations in the ERBB2 kinase domain. J Mol Diagn 2006, 8:351-356.

19. Travis WD, Brambilla E, Noguchi M, Nicholson AG, Geisinger KR, Yatabe $Y$, Beer DG, Powell CA, Riely GJ, Van Schil PE, et al: International association for the study of lung cancer/american thoracic society/european respiratory society international multidisciplinary classification of lung adenocarcinoma. Journal of thoracic oncology: official publication of the International Association for the Study of Lung Cancer 2011, 6:244-285.

20. Kim IJ, Kang HC, Shin Y, Park HW, Jang SG, Han SY, Lim SK, Lee MR, Chang $\mathrm{HJ}, \mathrm{Ku} J \mathrm{~L}$, et al: A TP53-truncating germline mutation (E287X) in a family with characteristics of both hereditary diffuse gastric cancer and LiFraumeni syndrome. J Hum Genet 2004, 49:591-595.

21. Lynch TJ, Bell DW, Sordella R, Gurubhagavatula S, Okimoto RA, Brannigan BW, Harris PL, Haserlat SM, Supko JG, Haluska FG, et al: Activating mutations in the epidermal growth factor receptor underlying responsiveness of non-small-cell lung cancer to gefitinib. N Engl J Med 2004, 350:2129-2139.

22. Sagawa M, Saito Y, Fujimura S, Linnoila Rl: K-ras point mutation occurs in the early stage of carcinogenesis in lung cancer. Br J Cancer 1998, 77:720-723.

23. Curry JD, Glaser MC, Smith MT: Real-time reverse transcription polymerase chain reaction detection and quantification of $t(1 ; 19)$ (E2A-PBX1) fusion genes associated with leukaemia. Br J Haematol 2001, 115:826-830.

24. Mazieres J, You L, He B, Xu Z, Lee AY, Mikami I, McCormick F, Jablons DM: Inhibition of Wnt16 in human acute lymphoblastoid leukemia cells containing the $\mathrm{t}(1 ; 19)$ translocation induces apoptosis. Oncogene 2005, 24:5396-5400.

25. Bamford S, Dawson E, Forbes S, Clements J, Pettett R, Dogan A, Flanagan A, Teague J, Futreal PA, Stratton MR, Wooster R: The COSMIC (Catalogue of Somatic Mutations in Cancer) database and website. Br J Cancer 2004, 91:355-358.

26. Shigematsu H, Takahashi T, Nomura M, Majmudar K, Suzuki M, Lee $H$, Wistuba II, Fong KM, Toyooka S, Shimizu N, et al: Somatic mutations of the HER2 kinase domain in lung adenocarcinomas. Cancer Res 2005, 65:1642-1646.

27. Dang TP, Gazdar AF, Virmani AK, Sepetavec T, Hande KR, Minna JD, Roberts JR, Carbone DP: Chromosome 19 translocation, overexpression of Notch3, and human lung cancer. J Natl Cancer Inst 2000, 92:1355-1357.

28. Soda M, Choi YL, Enomoto M, Takada S, Yamashita $Y$, Ishikawa S, Fujiwara S, Watanabe $H$, Kurashina K, Hatanaka $H$, et al: Identification of the transforming EML4-ALK fusion gene in non-small-cell lung cancer. Nature 2007, 448:561-566

29. Tomlins SA, Laxman B, Dhanasekaran SM, Helgeson BE, Cao X, Morris DS, Menon A, Jing X, Cao Q, Han B, et al: Distinct classes of chromosomal rearrangements create oncogenic ETS gene fusions in prostate cancer. Nature 2007, 448:595-599. 
30. Tomlins SA, Rhodes DR, Perner S, Dhanasekaran SM, Mehra R, Sun XW, Varambally S, Cao X, Tchinda J, Kuefer R, et al: Recurrent fusion of TMPRSS2 and ETS transcription factor genes in prostate cancer. Science 2005, 310:644-648.

31. Raz DJ, He B, Rosell R, Jablons DM: Current concepts in bronchioloalveolar carcinoma biology. Clin Cancer Res 2006, 12:3698-3704.

doi:10.1186/1756-9966-32-29

Cite this article as: Mo et al:: Detection of E2A-PBX1 fusion transcripts in human non-small-cell lung cancer. Journal of Experimental \& Clinical

Cancer Research 2013 32:29.

\section{Submit your next manuscript to BioMed Central} and take full advantage of:

- Convenient online submission

- Thorough peer review

- No space constraints or color figure charges

- Immediate publication on acceptance

- Inclusion in PubMed, CAS, Scopus and Google Scholar

- Research which is freely available for redistribution 